UDC 621.039

Doi: https://doi.org/10.32918/nrs.2019.1(81).07

\section{Analysis of Reliability-Critical Hydraulic Impact Conditions at WWER-1000 NPP Active Safety Systems}

\author{
Skalozubov V. \\ Odessa National Polytechnic University, Odessa, Ukraine \\ ORCID: https://orcid.org/0000-0003-2361-223X \\ Kozlov I. \\ Odessa National Polytechnic University, Odessa, Ukraine \\ ORCID: https://orcid.org/0000-0003-0435-6373 \\ Chulkin O. \\ Odessa National Polytechnic University, Odessa, Ukraine \\ ORCID: https://orcid.org/0000-0001-5048-4515 \\ Komarov Yu. \\ Odessa National Polytechnic University, Odessa, Ukraine \\ ORCID: https://orcid.org/0000-0002-4696-6551 \\ Piontkovskyi O. \\ Odessa National Polytechnic University, Odessa, Ukraine \\ ORCID: https://orcid.org/0000-0002-8859-0820
}

An original method to determine the onset of conditions for reliability critical hydraulic impacts for reliability analysis of active safety systems of nuclear power installations is proposed. The suggested method is based on determining the effect of head-flow characteristic delay onto hydraulic impact preconditions during the changes of pipeline system hydrodynamic parameters under transitional modes (e.g. in pump start-up). The delay time of responses to change in the hydrodynamic system parameters embodies the determining factor of head-flow characteristic's inertance, depending on both design and technical parameters of system components (including pumps), and the hydrodynamic parameters change rate under transitional modes.

Using the proposed method, the analysis of conditions for critical hydraulic impacts is performed for the primary high-pressure safety injection system of serial WWER-1000 nuclear power plants. The analysis results allow a conclusion that for this system the conditions leading to hydraulic impact due to the pump start are not reached.

The developed method can be applied to any thermal and nuclear power facilities' pipeline systems equipped with pumps.

Keywords: pump, hydraulic impact, response delay, head-flow characteristic.

(C) Skalozubov V., Kozlov I., Chulkin O., Komarov Yu., Piontkovskyi O., 2019
$\mathbf{R}$ esearch relevance. Increasing the reliable operation of thermal and nuclear power plant pumps represents a high relevance task for ensuring safe NPP operation. A large number of scientific studies has been devoted to the increase in the reliability of power system pumps, being aimed primarily at developing more reliable and improved pumping equipment, upgrading pumping system individual components, reducing their vibration level, with the increase of steady performance level, qualifying pumps' performance in accident conditions etc. [1-12].

In analyzing the reliability probabilistic indicators, given in the Safety Analysis Reports of Ukrainian nuclear power plants (NPP), for WWER-1000 NPP active safety system (ASS) components, the study showed that the least reliable ASS components are pumps and valves, and the greatest probability of failure takes place in pump start-up. Therefore, the issues of increasing the ASS pumps' reliable operation are relevant for ensuring the required safety level of WWER-1000 NPPs.

Assessing the possible reasons for the relatively low reliability of ASS pumps, we consider among most probable the hydraulic impacts (HI) on pumps' operating components in transient and operating modes. The HI is accompanied by impulse hydrodynamic impact on equipment and local hydraulic resistances of pipeline systems. At critical hydraulic impacts (CHI) the failure of respective equipment (including pumps) occurs.

In addition, numerous studies have been devoted to the conditions of $\mathrm{HI}$ occurrence and elimination in pipeline systems (e.g. [13-17]). However, the main limitations for the application of known results on determining the conditions for HI occurrence and elimination to ASS pumps are related to the following provisions.

1. We assume that resonant effects are the mechanisms determining fluctuations in hydrodynamic parameters (pressure and flow velocity): coincidence between the pipeline system natural frequency and the one of pumped working fluid. However, the resonant mechanism corresponds to extremely particular cases of HI occurrence and is not critical for most of the pumps in transient and emergency modes.

2. CHI emergence conditions which result in the pump failure during its start-up or operation are not defined.

3. Technical measures to reduce fluctuations in hydrodynamic parameters to avoid HIs are mainly implemented for the pipeline system components located downstream the pumps. These technical measures do not eliminate the preconditions for $\mathrm{CHI}$ at pumps.

The methods to identify the HI onset conditions due to the pumps' inertance under stationary modes are discussed in references [18-20].

Thus, the relevant problem consists in both definition and analysis of conditions leading to safety-critical HI in NPP ASS transient modes.

Main provisions of the method for determining CHI preconditions at pumps.

The $\mathrm{CHI}$ determining mechanism at pressure pumps refers to the pump's head-flow characteristic (HFC) delay:

$$
\Delta P_{\mathrm{p}}=f(G) ; \Delta P_{\mathrm{p}}=f(v),
$$

where $\Delta P_{p}$ is the pump head; $G, v$ are the flow rate and average velocity, respectively.

The HFC is determined by the specific pumps' design and technical characteristics.

The pump HFC delay here means the response time lag needed for change in the pipeline system hydrodynamic 


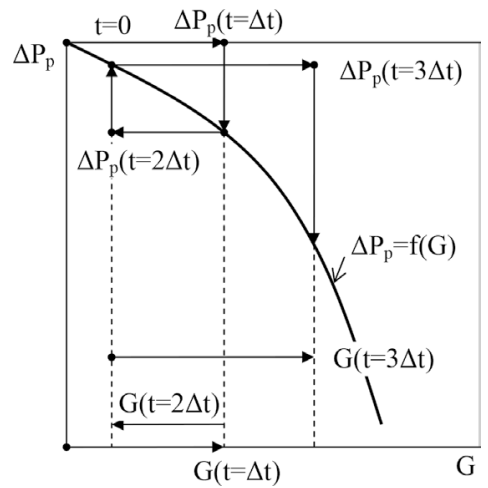

Fig. 1. Formation of hydraulic impact conditions taking into account the pump head-flow delay and flow characteristics in the transient mode (starting the pump) parameters under transient modes (e.g. at pump start-up). The pump HFC delay determining parameter is the delay time $\Delta \mathrm{t}$ of system feedback to the change in system's hydrodynamic parameters, which depends both on the design and technical characteristics of system components (including pump) and on the hydrodynamic parameters' change rate in transient mode.

Figure 1 shows an example of $\mathrm{HI}$ conditions formed at a pressure pump, taking into account the HFC delay in the transient mode (starting the pump).

At the pump's start, the head is the maximum. Further increase in the pipeline system flow according to the design HFC should lead to a feedback reducing the pump head. However, this HFC feedback does not occur instantaneously, but because of the hydrodynamic processes' inertance, with some delay $\Delta \mathrm{t}$. Therefore, at subsequent time moments $(\Delta t<t \leq 2 \Delta t)$, there will be a decrease in flow rate and a corresponding HFC increase in the pump head. Further, due to the hydrodynamic processes' inertance in the time interval $2 \Delta t<t \leq 3 \Delta t$, the corresponding HFC increase in the flow rate and pump head drop will occur with a delay.

Thus, due to HFC inertance, the pipeline system hydrodynamic parameters fluctuate relative to the HFC design curve. The effect of HFC inertia on the hydrodynamic parameters' fluctuation amplitude will be insignificant under the condition (see curves 1 and 2 in Fig. 2):

$$
\mathrm{I}=\frac{\Delta t G_{0}}{\rho F L}<<1,
$$

where I is the HFC inertia parameter; $G_{0}$ is the mass flow in the system under steady-state conditions; $\rho$ is the fluid density; $F$ is the pipeline section equivalent area; $L$ is the pipeline total length.

The inertance parameter can be presented in the simplified form by A.V. Korolev's formula:

$$
\mathrm{I}=\frac{\Delta t G_{0}}{\rho F L}=\frac{\Delta t \cdot W \cdot F \cdot \rho}{\rho \cdot F \cdot L}=\frac{\Delta t \cdot W}{L}=\frac{\Delta t}{\Delta T},
$$

where $\Delta t$ is the delay time and $\Delta T$ is the time required for fluid element passage along the whole pipeline at constant flow.

As inertia I parameter increases, the hydrodynamic parameters' fluctuation amplitude increases and reaches the limits, values determining preconditions for $\mathrm{CHI}$ occurrence (see curves 3 and 4 in Fig. 2).

$\mathrm{CHI}$ - area of mode parameters that correspond to the CHI conditions
Fig. 2. Regions of mode parameters corresponding to the conditions of critical hydraulic impacts at pumps:

1 - flow at relatively low HFC inertia;

$2-$ pump head at relatively low HFC inertia; 3 - flow rate at extreme HFC inertia; 4 - pump head at the maximum HFC inertia;

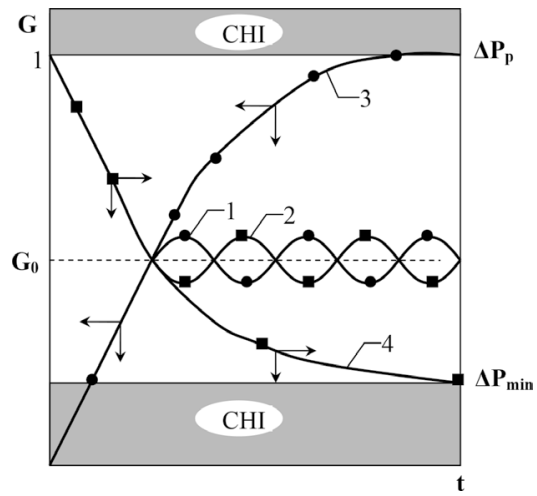

Under the assumptions of fluid incompressibility and isothermal processes, the flow equations for the considered pipeline system and the current change in the pump hydrodynamic head are:

$$
\begin{gathered}
\rho L \frac{\mathrm{d} v}{\mathrm{~d} t}=\Delta P_{\mathrm{p}}(v)+P_{1}-P_{2}-\Delta P_{1}(v)-\Delta P_{2}(v), \\
\Delta P_{\mathrm{pm}=}=\Delta P \quad+\int_{0}^{t} f^{\prime}(v) \frac{\mathrm{d} v}{\mathrm{~d} \tau} \mathrm{d} \tau
\end{gathered}
$$

At initial conditions

$$
\begin{gathered}
v(t=0)=0, \\
\Delta P_{\mathrm{p}}(t=0)=\Delta P_{\mathrm{pm}},
\end{gathered}
$$

where $\rho$ is the medium flow density; $L$ is the pipeline length; $\Delta P_{\mathrm{pm}}$ is the maximum possible hydrodynamic head of the pump, determined by its technical characteristics; $t$ is current time; $\mathrm{v}$ is the average velocity; $f$ ' is the current sensitivity of the pump's flow characteristic; $P_{1}, P_{2}$ are static pressure in the source and target, respectively.

Pressure losses in suction line $\mathrm{L}_{1}$ and charging line $\mathrm{L}_{2}$ can be calculated using the following formulas:

$$
\begin{aligned}
& \Delta P_{1}=\left[\xi_{\mathrm{pf}} \frac{L_{1}}{D}+\sum_{i=1} \xi_{\mathrm{fli}}\left(L_{1}\right)\right] \rho v^{2}-\rho g \sum_{j=1} h_{j} \operatorname{sign}\left[v_{j}\left(L_{1}\right)\right], \\
& \Delta P_{2}=\left[\xi_{\mathrm{pf}} \frac{L_{2}}{D}+\sum_{i=1} \xi_{\mathrm{fli}}\left(L_{2}\right)\right] \rho v^{2}-\rho g \sum_{j=1} h_{j} \operatorname{sign}\left[v_{j}\left(L_{2}\right)\right],
\end{aligned}
$$

where $\xi_{p f}, \xi_{f l i}$ are the pipeline friction and form loss factors, respectively; $D$ is the pipeline cross-section diameter; $g$ is the gravity acceleration; $h_{\mathrm{j}}$ is the height of the pipeline system vertical sections;

$$
\operatorname{sign}(v)=\left\{\begin{array}{l}
1, \text { descending _flows } \\
-1, \text { ascending _ flows }
\end{array}\right.
$$

The supply (network) characteristic sensitivity to changes in flow rate/flow velocity is:

$$
f^{\prime}=\frac{\mathrm{d} \Delta P_{\mathrm{p}}}{\mathrm{d} G} \text { or } f^{\prime}=\frac{\mathrm{d} \Delta P_{\mathrm{p}}}{\mathrm{d} v}
$$


For pressure pumps, the supply (network) characteristics design sensitivity is:

$$
f^{\prime}(G, v) \leq 0 .
$$

$\mathrm{CHI}$ conditions for the pump at the maximum permissible (critical) velocity are:

$$
v \geq v_{\max }=\min \left\{\begin{array}{l}
\sqrt{\frac{2 N_{\max }}{\rho}}, \\
\sqrt{\frac{2\left[P_{1}\left(L_{1}\right)-P_{\mathrm{S}}\right]}{\rho}} .
\end{array}\right.
$$

where $N_{\max }$ is the maximum admissible hydrodynamic load on the pump working components.

Pump CHI conditions at pump minimum permissible head $\Delta P_{\min }$ are:

$$
2 \leq \Delta P_{\min }=P_{1}-P_{2}-\Delta P_{1}-\Delta P_{2} .
$$

Results of computational modeling. The above method for determining the pumps' CHI emergence conditions was applied to the following ASSs of WWER-1000 NPPs:

high-pressure safety boron injection system TQ13;

high-head safety boron injection system TQ14.

Structural and technical characteristics for components of the TQ13 and TQ14 systems (including pumps and their HFCs) are presented in [22].

Pumps' HFC are defined with the approximation of design relations:

$$
\Delta P_{\mathrm{p}}=\sum_{i=1}^{n} a_{i} v^{i}
$$

where $a_{i}$ are the approximation coefficients for a specific pump type.

Conservatively (in relation to HFC inertance), the hydraulic resistance coefficients of pipeline systems and pumps are assumed constant.

Equations (4) - (14) for the TQ13 and TQ14 systems have been solved using a mathematical model with the Runge-Kutta numerical method.

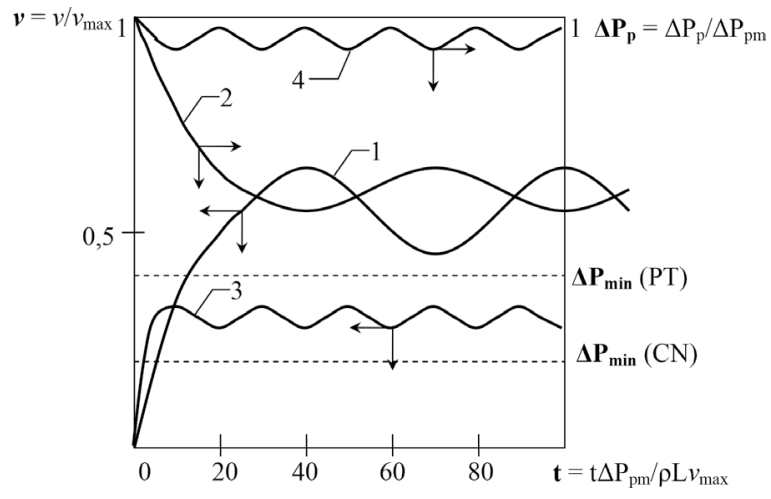

Fig. 3. Results of computational modeling of fluctuations in hydrodynamic parameters in start-up of TQ13,14 safety system pumps:

1 - relative average velocity at starting pumps CN $150-110$, CN 160-110;

$2-$ relative pressure of pumps

CN 150-110, CN 160-110;

3 - relative average flow rate at starting pumps PT $6 / 160-\mathrm{C}$;

4 - relative head of pumps PT 6/160-C
The main results of computational modeling are shown in Fig. 3 and are as follows.

1. For both TQ13 and TQ14 systems, there are no conditions for $\mathrm{CHI}$ occurrence in pump start-up:

$$
\frac{v(t)}{v_{\max }}<1 ; \quad \Delta P_{\mathrm{p}}(t) \leq \Delta P_{\min }
$$

2. Variations in the hydrodynamic parameter amplitudes and oscillation frequencies for different types of pumps are determined by their HFC differences: for CN50/160-110 pumps, HFC is similar to the HFC curve shown in Fig. 2; and for PT16-C pumps, HFC is much less inertial.

3. The obtained results testifying that there are no conditions under which the CHI would occur in start-up of TQ13 and TQ14 pumps are quite conservative, since the assumptions accepted in computational modeling determine the limiting conditions for the CHI emergence. Thus, for example, when the nonstationary nature of hydraulic resistance coefficients for valves is more realistically taken into account in pump startup, the effect of HFC inertance onto preconditions for $\mathrm{CHI}$ occurrence is less significant.

\section{Conclusions}

1. To analyze the reliability of nuclear power plant active safety systems, an original method for determining the conditions for the critical (for operability) hydraulic impacts at pipeline system components in transient operation modes is proposed.

The proposed method is based on the inertance of the headflow pump characteristic determining the effect on the conditions involving hydraulic impact occurrence when the pipeline system hydrodynamic parameters change in transient modes (for example, when pumps are starting). The determining factor for inertia of the pressure-supply characteristic is the delay time of response to the change in the system hydrodynamic parameters, which depends both on the structural and technical parameters of system components and on the hydrodynamic parameters' change rate in transient modes.

2. It is established that with a sufficiently large inertance of pumps' pressure-head characteristic, the critical hydraulic impact may occur on the pumps both at the maximum permissible flow rate in the system and at the minimum allowable pump head.

3. Using the developed method, the conditions for the CHI occurrence at components of the primary emergency boron injection systems of serial power units with WWER-1000 reactors have been analyzed.

The analysis shows that for all systems considered, there are no conditions for the critical hydraulic impacts in pump start-up.

4. The proposed method can be applied to any pipeline systems of thermal and nuclear power plants that include pressure pumps.

\section{References (BSI)}

1. Brennen, C. E. (2011), Hydrodynamics of pumps, Cambridge University Press, 304 p.

2. Jelali, M., Kroll, A. (2012), Hydraulic servo-systems: modelling, identification and control, Springer Science \& Business Media, 356 p.

3. Grin'ko, L. P., Papira, A. N (1975), Blade pumps [Lopastnyye nasosy], L.: Mechanical Engineering, Leningrad, 432 p. (Rus) 
4. Derakhshan, S., Nourbakhsh, A. (2008), "Theoretical, numerical and experimental investigation of centrifugal pumps in reverse operation", Experimental Thermal and Fluid Science, V. 32, No. 8, pp. $1620-1627$.

5. Mollazade, K., et al. (2008), "An intelligent combined method based on power spectral density, decision trees and fuzzy logic for hydraulic pumps fault diagnosis", Parameter, V. 186, p. 11829. doi https://doi.org/10.5281/zenodo.1055695).

6. Li, S. C. (ed.) (2000), Cavitation of hydraulic machinery, V. 1, World Scientific, $492 \mathrm{p}$.

7. Li, G., Xu Y., Hao S. (2007), "A New Circuit in Double Pumps Hydraulic System of Modular Machine Tool's Power Sliding Feed Table and Its PLC Control", Modular Machine Tool \& Automatic Manufacturing Technique, V. 6, p. 021.

8. Chaichan, Miqdam Tariq, Al-Zubaidi, Dina Saadi Muneam (2017), "Control of hydraulic transients in the water piping system in Badra-pumping station No. 5", Al-Nahrain Journal for Engineering Sciences, 18.2, pp. 229-239.

9. Broussard, Joel N., et al. (2017), Torsional coupling for electric hydraulic fracturing fluid pumps, U.S. 9,650,879, United States Patent.

10. Sivaramakrishnan, Shyam, et al. (2017), Hydraulic control system for a reverse osmosis hydraulic pump, U.S. 9,638,179, United States Patent.

11. Cryer, Robert Douglas, et al. (2017), System and method for powering a hydraulic pump, U.S. 9,579,980, United States Patent.

12. Amirov, Fikrat E. (2017), "Investigations of hydrodynamically active additions in pumps and vane hydraulic machines", EGU General Assembly Conference Abstracts, V. 19. (2017EGUGA.1912550A)

13. Zhukovskiy, N. E. (1949), On hydrodynamic impact in water supply systems. [O gidrodinamicheskom udare $\mathrm{v}$ vodoprovodnykh sistemakh], GITTL, 100 p. (Rus)

14. Accidents at boiler inspection facilities and measures to prevent them, Gosgortechnadzor's Newsletter (1965) [Avarii na ob"yektakh kotlonadzora i mery po ikh preduprezhdeniyu, Informatsionnoye pis'mo Gosgortekhnadzora], Nedra, Moscow, 174 p. (Rus)

15. Khachaturyan, S. A. (1983), Wave processes in compressor units [Volnovye protsessy v kompressornykh ustanovkakh], Mashinostroenie, Moscow, $222 \mathrm{p}$

16. Gerliga, V. A., Khabenskiy, V. B. (1994), Instability of the coolant flow in power equipment [Nestabil'nost' potoka teplonositelya $\mathrm{v}$ energooborudovanii], Energoizdat, Moscow, $288 \mathrm{p}$.

17. Korolev, A. V., Zhou Hui Yu (2016), "Research of dynamics at normal operation and interrupted feed of piston pumps" [Issledovaniye dinamiki porshnevogo nasosa $\mathrm{v}$ normal'nom rezhime i pri sryve podachi], Refrigeration Engineering and Technology, V. 52, Issue 52, pp. 4-8. doi https://doi.org/10.15673/ret.v52i5.282)

18. Mazurenko, A. S., Skalozubov, V. I., Kozlov, I. L., Chulkin, O. A., Pirkovskiy, D. S (2017), "Determining the Conditions for the Hydraulic Impacts Emergence at Hydraulic Systems", Problemele energeticii regionale, Termoenergetica, Moldova, 2 (34), pp. 98-104.

19. Skalozubov, V. I. Zhou Huiyu, Chulkin, O. A., Pirkovskiy, D. S. (2017), "Modelling method of conditions for reliability-critical hydraulic impacts on pumps of thermal and nuclear power plants", Problems of Atomic Science and Technology, № 4 (110), pp. 74-78.

20. Skalozubov, V. I, Chulkin, O. A, Pirkovskii, D. S (2017), "Determination of preconditions for hysroimpacts in hydraulic systems [Vyznachennya umov vynyknennya hidroudariv u hidrosystemakh]", Modern problems of refrigeration equipment and technology / Collection of abstracts presented at the XI All-Ukrainian scientific and technical conference, ONACHT, Odessa, p. 193 (Rus).

21. Skalozubov V. I., Oborsky G. A., Kozlov I. L et al. (2013), A complex of methods for reassessing the nuclear power engineering safety in Ukraine, taking into account lessons of ecological disasters in Chernobyl and Fukushima [Kompleks metodov pereotsenki bezopasnosti atomnoy energetiki Ukrainy s uchetom urokov ekologicheskikh katastrof $\mathrm{v}$ Chernobyle i Fukusime]: monograph: Astroprint, Odessa, $242 \mathrm{p}$

22. 00.UTs.RO.Ps.317 Emergency boron injection system (TQ13) High-pressure boron injection system (TQ14) [Sistema avariynogo vvoda bora (TQ13). Sistema avariynogo vvoda bora vyisokogo davleniya (TQ14) : 00.UTs.RO.Ps.317], NNEGC «Energoatom», Zaporizhzhya NPP, 2008.
Анализ критических условий надежности при гидроударах в активных системах безопасности ядерных энергетических установок с ВВЭР-1000

Скалозубов В. И., Козлов И. Л., Чулкин О. А., Комаров Ю. А., Пионтковский О. И.

Одесский национальный политехнический университет, г. Одесса, Украина

Для анализа надежности активных систем безопасности ядерных энергетических установок предложен оригинальный метод опреде ления условий возникновения критических (для работоспособности) гидравлических ударов. Предлагаемый метод основан на определяющем влиянии инерционности напорно-расходной характеристики на условия возникновения гидроударов при изменении гидродинамических параметров в трубопроводной системе в переходных режимах (например, при запуске насосов). Определяющим фактором инерционности напорно-расходной характеристики является время запаздывания обратных реакций на изменение гидродинамических параметров в системе, которое зависит как от конструкционно-технических параметров элементов системы (в том числе и насосов), так и от скорости изменения гидродинамических параметров в переходных режимах

На основе разработанного метода проведен анализ условий возникновения критических гидроударов в системе аварийного ввода бора в первый контур серийных энергоблоков с реакторами типа ВВЭР1000. В результате проведенного анализа установлено, что для рассмотренной системы отсутствуют условия возникновения критических гидроударов при запуске насосов.

Предложенный метод может быть распространен на любые трубопроводные системы тепловых и ядерных энергетических установок в состав которых входят напорные насосы.

Ключевы е слова: насос, гидроудар, инерционность, напорнорасходная характеристика.

Аналіз критичних умов надійності при гідроударах В активних системах безпеки ядерних енергетичних установок з ВВЕР-1000

Скалозубов В. І., Козлов І. Л., Чулкін О. О., Комаров Ю. О., Піонтковський О. І.

Одеський національний політехнічний університет, м. Одеса, Україна

Для аналізу надійності активних систем безпеки ядерних енер гетичних установок запропоновано оригінальний метод визначення умов виникнення критичних (для працездатності) гідравлічних ударів. Пропонований метод засновано на визначальному впливі інерційності напірно-витратної характеристики на умови виникнення гідроударів при зміні гідродинамічних параметрів у трубопровідній системі в перехідних режимах (наприклад, при запуску насосів). Визначальним чинником інерційності напірно-витратної характеристики $\epsilon$ час запізнювання зворотних реакцій на зміну гідродинамічних параметрів у системі, який залежить як від конструкційно-технічних параметрів елементів системи (у тому числі і насосів), так $і$ від швидкості зміни гідродинамічних параметрів у перехідних режимах.

На основі розробленого методу проведений аналіз умов виникнення критичних гідроударів в системі аварійного введення бору в перший контур серійних енергоблоків з реакторами типу ВВЕР-1000. У результаті проведеного аналізу встановлено, що для розглянутої системи відсутні умови виникнення критичних гідроударів при запуску насосів.

Запропонований метод може бути поширений на будь-які трубопровідні системи теплових і ядерних енергетичних установок, до складу яких входять напірні насоси.

Ключов і слов а: насос, гідроудар, інерційність, напірно-витратна характеристика. 